\title{
Hierarchical Optical Character Recognition System Design Based on the Hopfield Neural Networks
}

\author{
Nataša Kljajić ${ }^{1)}$ \\ Željko Đurović ${ }^{2}$
}

\begin{abstract}
Pattern recognition is a scientific discipline dealing with the methods for object description and classification and the Optical Character Recognition (OCR) is one of its fields of research. In this paper a hierarchical optical character system design is presented. Classification strategy based on the Hopfield neural networks and image processing methods are described. The characters for recognition are Cyrillic alphabet capital letters. The first step in the design is a neural network testing with the real scanned document in order to see how the network works. Based on the results of testing with one Hopfield neural network, some common sources of error in this system were found. These sources of error were a base for new improvements in the system. Next step is, therefore, the addition of new binary image processing parameters and new pre-processing and post-processing techniques for a typical error's elimination. After testing the same real scanned document again, the obtained results showed that this new and improved system decreased an error probability significantly
\end{abstract}

Key words: pattern recognition, character recognition, optical recognition, pattern recognition system, hierarchy system, neural network, associative memory.

\section{Introduction}

$\mathrm{O}$ BJECT recognition is a task performed daily by living beings and is inherent to their ability and necessity to deal with the environment. It is performed in the most varied circumstances. The development of the methods capable of emulating the most varied forms of the object recognition has evolved along with the need for building intelligent automated systems. In these systems objects are represented in a suitable way for the type of processing they are subject to. Such representations are called patterns. Pattern recognition is a scientific discipline dealing with the methods for object description and classification [1].

Human visual performance greatly exceeds computer capabilities, probably because of superior high-level image understanding, contextual knowledge, and massively parallel processing. Human capabilities deteriorate drastically in a low-visibility environment or after an extended period of surveillance, and certain working environments are either inaccessible or too hazardous for human beings. For these reasons, automatic recognition systems are developed and used for various military applications [2]. Algorithms used in missile guidance, image processing and target recognition in Unmanned Aerial Vehicles (UAV), radar systems all rely on the pattern recognition techniques.

Optical character recognition (OCR) as a part of the image processing system is a field of research in the pattern recognition. Optical character recognition is a powerful tool for bringing information from our analog lives into our increasingly digital world. This technology has long seen use in the document imaging; by scanning or photographing documents we may convert them into soft copies that can be edited, searched, reproduced and transported with ease. With digitally reproduced information at our fingertips, the world's business, research, and governmental spheres grow more productive [3].

The goal of this paper is to present a recognition technique that outcomes the complications that natural scenes bring to OCR process. Classification strategy based on the Hopfield neural networks and image processing methods is described. Recognition algorithm design approach is divided into two steps. The first step tests a neural network and its common error sources concerning recognition of certain characters. This step determines a base for the algorithm improvement methods described in the next step. By adding new techniques to the recognition system design, besides the Hopfield neural networks as an algorithm base, error probability of the system decreases significantly. Algorithm is tested on a real scanned document. All software was written in Matlab programming language.

\section{Computer vision}

Computer vision is a field that includes methods for analyzing information that are present in images by using some artificial systems. It is used in visual navigation systems in target recognition and target tracking systems, which can be found in payloads of the UAVs or in homing heads of missiles [4]. Methods of computer vision included in this paper are image processing techniques and also pattern recognition algorithms.

\footnotetext{
1) Military Technical Institute (VTI), Ratka Resanovića 1, 11132 Belgrade, SERBIA

2) University of Belgrade, Faculty of Electrical Engineering, Bulevar Kralja Aleksandra 73, 11000 Belgrade, SERBIA

Correspondence to: natasha.kljajic@yahoo.com
} 
In an image processing we use different techniques, such as: filtering (operations that as a result provide a modified image with the same dimensions as the original image), data reduction (any operation that extracts significant components from the image), segmentation (any operation that partitions the image into regions that are coherent with respect to some criterion), object detection (determining the position and, possibly, the orientation and scale of the specific objects in the image, and classifying these objects), image understanding (obtaining high level knowledge of what the image shows), optimization. We also have different abstraction levels of the input data. The abstraction level we use in this paper is pixel level where the intensities of individual pixels are provided as an input to the algorithm [5]. In this paper, the analyzed image is converted into a binary image, which is a sequence of black and white pixels, so we have zero and one as pixel intensity values.

Pattern recognition algorithm described in this paper uses one of the soft computing methods. Goal of soft computing is to enable tolerance of some imprecise data and the approximate reasoning in order to accomplish as much similarity as possible with human decision making and reasoning. Most significant soft computing techniques are fuzzy logic and neural networks. In this paper, a soft computing technique based on neural networks is represented and described [6].

\section{Associative memory}

Associative memory has been an active topic of research for more than 50 years and is still investigated both in neuroscience and in artificial neural networks. The basic observation of the association occurs when we try to find a specific piece of information in our memory and we do not retrieve it immediately. In such cases we notice that the present state of our mind or brain which presumably contains the aspects of the present situation and contextual information pointing at the missing piece (momentarily however not sufficient to find it), starts a sequential process of associations from one item to the next (possibly governed by a semantic similarity) that eventually ends with the missing piece. Once this piece of information is there, we immediately recognize it as what we have been searching for, since it somehow fits perfectly into the context that triggered our mental search. So, there seems to be a kind of information system in our brain that associates a new output to a given input depending on the contextual information (and perhaps its own previous state).

From a technical point of view there are two different mechanisms that are needed in this process of association: hetero-association (Bidirectional Associative memory), that leads from one pattern to the next, and auto-association (Recurrent Hopfield memory) from one pattern to itself, that is useful for the recognition of one pattern as the best fitting, or also for a slight correction or completion of this pattern, and thereby ending the chain of (hetero) associations [7].

\section{Hopfield neural networks}

Main goal of the neural networks is to model and imitate human brain. One of the basic characteristics of human brain is associative memory, retrieval of previous knowledge based on incomplete information. Associative neural networks represent a software simulation of this human attribute. In order to simulate the associative memory, there is a need for a recurrent type of neural networks. One example of a recurrent neural network is the Hopfield network created by John Hopfield in 1982 [7]. Two types of Hopfield neural networks can be used: discrete and continual, but in this paper discrete Hopfield neural networks are analyzed.

Hopfield neural network is a recurrent neural network with input-output feedback connections. These feedback connections make neural network able to recognize patterns. In the process of initialization of the network, an input pattern is used to initialize output pattern. After the initialization the input pattern is removed, and output becomes, throughout feedback connections, a new network input. This action is repeated until there exists a change in the output pattern. When there is no change of the output pattern, then the network is in the equilibrium. If the network does not reach equilibrium after a reasonable number of steps, then the process stops. In the Hopfield neural networks there are no feedback connections to the same neuron, because of the stability of the network [8].

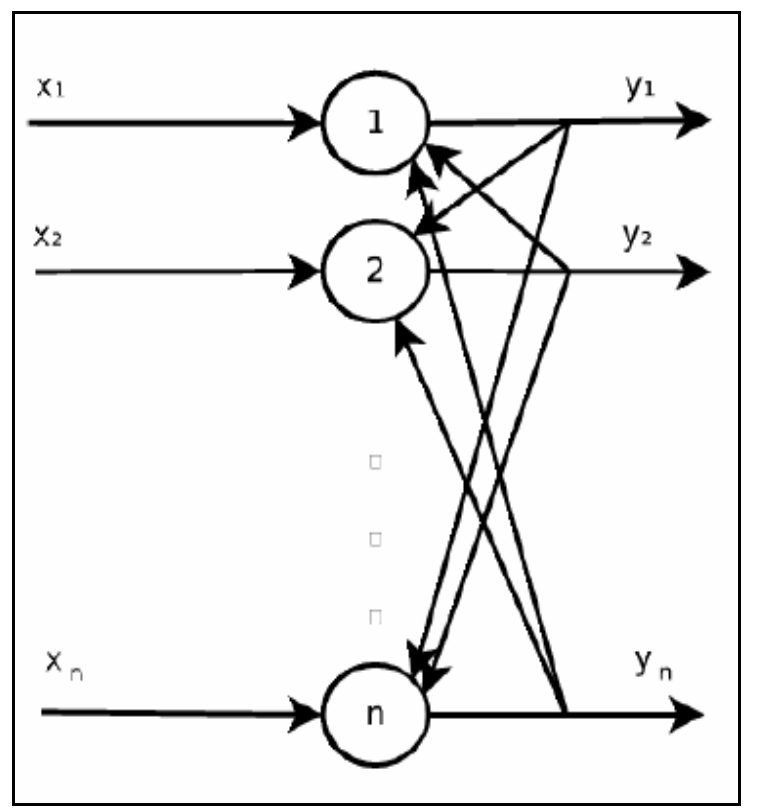

Figure 1. One layer Hopfield neural network

As for the network architecture, (Figure 1), the Hopfield network consists of $I$ neurons. They are fully connected through symmetric, bidirectional connections with weights $w_{i j}=w_{j i}$. There are no self-connections, so $w_{i i}=0$ for all $i$. Biases $w_{i 0}$ may be included (these may be viewed as weights from a neuron ' 0 ' whose activity is permanently $x_{0}$ $=1$ ), and the activity of neuron $i$ (its output) is $x_{i}$. The Hopfield network's activity rule is for each neuron to update its state as if it were a single neuron with the threshold activation function (1):

$$
\operatorname{signum}(x):= \begin{cases}+1 & x \geq 0 \\ -1 & x<0\end{cases}
$$

Since there is a feedback in the Hopfield network (every neuron's output is an input to all other neurons) an order for the updates to occur is specified. The updates may be synchronous or asynchronous. Synchronous updates - all neurons compute their activations, and then update their states simultaneously. Asynchronous updates - one neuron at a time computes its activation and updates its state. The sequence of the selected neurons may be a fixed sequence 
or a random sequence. The properties of the Hopfield network may be sensitive to these choices. The learning rule is intended to make a set of desired memories be stable states of the Hopfield network's activity rule. Each memory is a binary pattern, with $x_{i} \in\{-1,1\}$ [9].

Network capacity of the Hopfield neural network is a number of patterns that can be memorized by this neural network. It is experimentally proven by Hopfield himself, that the number of patterns is limited to $15 \%$ of the neuron number. For the Hopfield network with $\mathrm{n}$ neurons, limitation is (2):

$$
M_{\text {max }}=0.15 n
$$

Seven years later, Amit proved experimentally that for the perfect recognition of majority of patterns the limitation is (3):

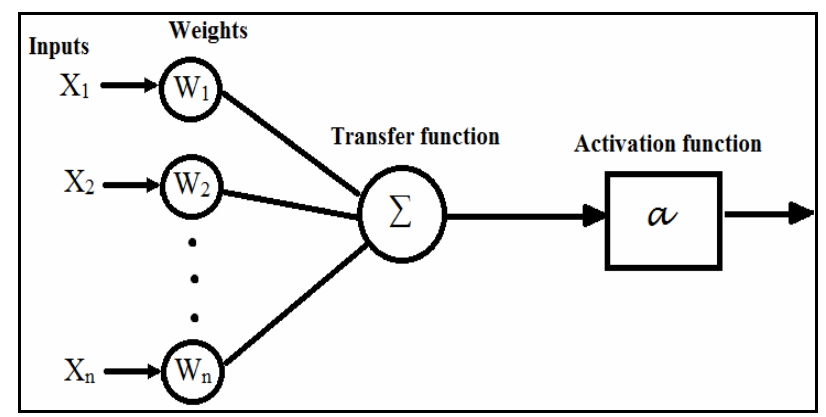

Figure 2. Structure of the Hopfield neural network

$$
M_{\max }=\frac{n}{2 \ln n}
$$

If it is necessary for the network to recall all memorized patterns, this number is (4):

$$
M_{\max }=\frac{n}{4 \ln n}
$$

\section{Hierarchical optical character recognition system design}

In the process of the recognition system design, two steps are important. First, we make a 30 characters base Hopfield neural network, and test it to see how this algorithm works. The next step is to examine the results and reveal some common error sources and badly recognized characters. By using some additional binary image processing parameters some new pre-processing and post-processing techniques are included in the general algorithm structure. In this step two neural networks are realized, in order to split the base of characters into two smaller groups that are more convenient for recognition by the Hopfield neural network.

Step one in the classification system design is a character classification with 30 characters base Hopfield neural network. This first approach is based on the Hopfield neural network recognition, where network base consists of all 30 Cyrillic letters, font Times New Roman, and size 12. The base was formed out of the scanned characters of the best quality. The goal is to create a network with a set of steady states that lead to a network steady state when the initial condition is provided. This is a recursive network. The algorithm is not perfect in a sense that network has some unstable states, except from given steady states, but it is made in a way that this number is the lowest possible. The design method is based on the first order differential equations. The structure of the used network is shown in Fig.2.

Hopfield neural network usually uses saturated linear function satlins shown in Fig.3. [10].

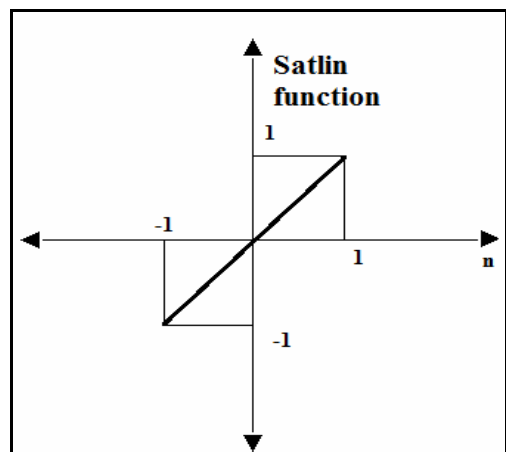

Figure 3. Satlin function

Before the image recognition of a scanned document this page was analyzed and processed, in order to prepare input characters for the network simulations. Since the color of the document is not relevant for recognition, the image was transformed into a binary image with 256 gray levels. Then, by using some image processing techniques, binary image was prepared for the character extraction. For the classification, it was necessary to prepare a base of characters to be recognized. Out of all the characters from scanned documents, representative characters for each letter were extracted. Now, the target matrix could be made. Number of rows of target matrix is a length of each character, and the number of columns is 30 , as there are 30 characters in the analyzed alphabet. Before the recognition it is necessary to adjust characters in the character base for a needed format of network input. This means that the image of a character is set to binary image with equal dimensions of each character (in pixels). When target matrix is made it represents a base of characters for the neural network. Now, a neural network for the character recognition was trained and tested with a real scanned document.

\section{ПАРИЗ} ПАРИЗ ЈЕ ГЛАВНИ И НАЛВЕ ИИ ГРАД
ФРАНЦУСКЕ

НАЛАЗИ СЕ У ЦЕНТРУ ПАРИСКОГ БАСЕНА НАД РЕКОМ СЕНОМ РЕКОМ ЈЕ ПОДЕЉЕН НА ДВА ДЕЛА НА СЕВЕРНУ ЛЕСНУ ОБАЛУ И НА ЈУЖНУ ЛЕВУ ОБАЛУ

ГРАД ПРЕДСТАВЈЬ ПОЛИТИЧКО ЕКОНОМСКО ОБРАЗОВНО И КУЛТУРНО СРЕДИШТЕ ЦЕНТРАЛИЗОВАНЕ ФРАНЦУСКЕ ДРЖАВЕ А И ЕВРОПЕ

ПАРИЗ ЈЕ ЈЕДАН ОД

НАЈЗНАЧАЈНИЈИХ СВЕТСКИХ

ГРАДОВА

У ЮЕМУ СУ СЕДИШТА

МЕ УНАРОДНИХ ОРГАНИЗАЦИЈА

УНЕСКО ОЕЦЛ И НЕФОРМАЛНОГ

ПАРИСКОГ КЛУБА

СА СВЕТОМ ЈЕ ПОВЕЗАН ПІРЕКО ДВА ВЕЛИКА АЕРОДРОМА И ШЕСТ

ГЛАВНИХ ЖЕЛЕЗНИЧКИХ СТАНИЦА

СА ИСТОРИЈОМ ДУГОМ ДВА

МИЛЕНИЈУМА ОВАЈ ГРАД ЈЕ БИО

МЕСТО ЗНАЧАЈНИХ И

ИСТОРИЈСКИХ ДОГАБАЈА И

СТЕЦИШТЕ УМЕТНИКА

ЗБОГ ТОГА СВАКЕ ГОДИНЕ ПАРИЗ

ПОСЕТИ ДО 30 МИЛИОНА ТУРИСТА

ПО БРОЈУ ТУРИСТА ПАРИЗ JF

НАЛОСЕКЕНИЈА СВЕТСКА
ТУРИСТИЧКА ДЕСТИНАЦИЛА

ТАКОБЕ ЈЕ ПОЗНАТ ПО ИМЕНУ ГРАД СВЕТЛОСТИ

\section{Figure 4. Scanned document used for testing}

The scanned document shown in a Fig.4 was used for testing.

\section{ГРАД ИМА ПРЕКО ДВА МИЛИОНА ПРЕКО ДЕСЕТ МИЛИОНА}

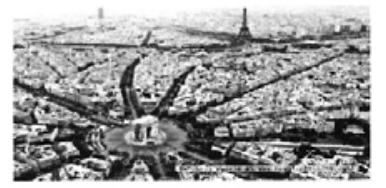

ПАРИЗ СЕ ПРОСТИРЕ НА ОКО СТО КВАЛРАТНИХ КИЛОМЕТАРА

PЕКА СЕНА ПОВЕЗУ JE ПАРИЗ СА УНУТРАШЬОШКУ ЗЕМљЕ И СА СНH РАЗЛОГ ЗА ОСНИВЕКЕ ЈЕ БИЛА OАЗО ЗА ОСНИВАЕ ТРАДА НА BATTOP

ОСТРВО ДЕ ЛА СИТЕ СЕ НАЛАЗИ У СРЦУ ГРАЛА И ТУ ЈЕ НАСТАЛО ПРВО НАСЕљЕ У ДОБА АНТИКЕ

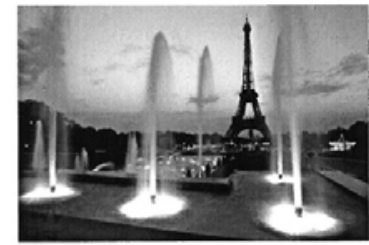

НАЛВИШЕ ПРИРОДНО УЗВИШЕњЕ У ГРАДУ ЈЕ БРДО МОНМАРТР ГДЕ СЕ ГРАДУ ЈЕ БРДО МОНМАРТР 
Testing had been done for all letters from the tested document, except for the article title, since the font was different than the font of the article. The results are shown in Table 1.

Table 1. Testing results of the character classification with 30 characters base Hopfield neural network

\begin{tabular}{||c|c||}
\hline Number of tested characters & 1025 \\
\hline Errors & 67 letters \\
\hline Error percentage & $6.54 \%$ \\
\hline
\end{tabular}

Table 2 gives a good perspective of the obtained results. Now it is clear what the weaknesses of the network used are, and what characters are very often badly recognized.
For the easier understanding of the testing results, the legend is shown in Table 3.

Based on these results, a conclusion is that the network works very bad for some letters. We can also see that there are typical errors for some specific letters. For example, common error is a bad recognition of the letter " $\mathrm{H}$ ".

This problem can be solved with the pre-classification and post-classification algorithms, used in the second approach explained in the next paragraph. These algorithms consider some additional characteristics of each character and represent important techniques in the image processing.

Table 2. Matrix representation of the results of character classification with 30 characters base Hopfield neural network

\begin{tabular}{|c|c|c|c|c|c|c|c|c|c|c|c|c|c|c|c|c|c|c|c|c|c|c|c|c|c|c|c|c|c|c|c|c|c|c|c|}
\hline & A & Б & B & $\Xi \Gamma$ & ¿ Д & & 万 & $\mathrm{E}$ & Ж & К & 3 & 1 & $\boldsymbol{J}$ & K & K & $\mathrm{J}$ & ১ & $\mathbf{I}$ & $\mathrm{H}$ & Њ & b & $\mathrm{O}$ & П & $\mathrm{P}$ & $\mathrm{C}$ & & $T$ & & $\mathrm{y}$ & $\Phi$ & X & Ц & Ч & Џ & Ш \\
\hline $\mathrm{A}$ & 135 & 0 & 0 & 0 & 0 & ) & 0 & 0 & 0 & 0 & 0 & 0 & 0 & 0 & 0 & 0 & 0 & 0 & 0 & 0 & 0 & 0 & 0 & 0 & 0 & & 0 & 0 & 0 & 0 & 0 & 0 & 0 & 0 & 0 \\
\hline Б & 0 & 13 & 0 & 0 & 0 & & 0 & 0 & 0 & $0 \vdots$ & 0 & 0 & 0 & 0 & 0 & 0 & 0 & 0 & 0 & 0 & 0 & 0 & 0 & 0 & 0 & & 0 & 0 & 0 & 0 & 0 & 0 & 0 & 0 & 0 \\
\hline$B$ & 0 & 0 & 33 & 0 & 0 & & 0 & 0 & 0 & 0 & 0 & 0 & 0 & 0 & 0 & 0 & 0 & 0 & 0 & 0 & 0 & 0 & 0 & 0 & 0 & & 0 & 0 & . & 0 & 0 & 0 & 0 & 0 & 0 \\
\hline$\Gamma$ & 0 & 0 & 0 & 24 & $1=0$ & ) & 0 & 0 & 0 & 0 & 0 & 0 & 0 & 0 & 0 & 0 & 0 & 0 & 0 & 0 & 0 & 0 & 0 & 0 & 0 & & 0 & 0 & 0 & 0 & 0 & 0 & 0 & 0 & 0 \\
\hline Д & 0 & 0 & 0 & 0 & 38 & 8 & 0 & 0 & 0 & 0 & 0 & 0 & 0 & 0 & 0 & 0 & 0 & 0 & 0 & 0 & 0 & 0 & 0 & 0 & 0 & & 0 & 0 & 0 & 0 & 0 & 0 & 0 & 0 & 0 \\
\hline 万 & 0 & 0 & 0 & 0 & 0 & ) & 3. & 0 & 0 & 0 & 0 & 0 & 0 & 0 & 0 & 0 & 0 & 0 & 0 & 0 & 0 & 0 & 0 & 0 & 0 & & 0 & 0 & 0 & 0 & 0 & 0 & 0 & 0 & 0 \\
\hline$E$ & 0 & 0 & 2 & 0 & 0 & ) & 0 & 98 & 0 & 0 & 0 & 0 & 0 & 0 & 0 & 0 & 0 & 0 & 0 & 0 & 0 & 0 & 0 & 0 & 0 & & 0 & 0 & 0 & 0 & 0 & 0 & 0 & 0 & 0 \\
\hline Ж & 0 & 0 & 0 & 0 & 0 & ) & 0 & 0 & 4 & 4 & 0 & 0 & 0 & 0 & 0 & 0 & 0 & 0 & 0 & 0 & 0 & 0 & 0 & 0 & 0 & & 0 & 0 & 0 & 0 & 0 & 0 & 0 & 0 & 0 \\
\hline 3 & 0 & 0 & 0 & 0 & 0 & ) & 0 & 0 & 0 & $0: 2$ & 26 & 0 & 1 & 0 & 0 & 0 & 0 & 0 & 0 & 0 & 0 & 0 & 0 & 0 & 0 & & 0 & 0 & 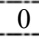 & 0 & 0 & 0 & 0 & 0 & 0 \\
\hline И & 0 & 0 & 0 & 0 & 0 & & 0 & 0 & 0 & 0 & 03 & 85 & 0 & 0 & 0 & 0 & 0 & 0 & 30 & 0 & 0 & 0 & 0 & 0 & 0 & & 0 & 0 & 0 & 0 & 0 & 0 & 0 & 0 & 0 \\
\hline $\mathrm{J}$ & 0 & 0 & 0 & 0 & 0 & ) & 0 & 0 & 0 & 0 & 0 & 0 & 32 & 0 & 0 & 0 & 0 & 0 & 0 & 0 & 0 & 0 & 0 & 0 & 0 & & 0 & 0 & 0 & 0 & 0 & 0 & 0 & 0 & 0 \\
\hline $\mathrm{K}$ & 0 & 0 & 0 & 0 & 0 & ) & 0 & 0 & 0 & 0 & 0 & 0 & 0 & 37 & 7 & 0 & 0 & 0 & 0 & 0 & 0 & 0 & 0 & 0 & 0 & & 0 & 0 & 0 & 0 & 0 & 0 & 0 & $\vdots 0$ & 0 \\
\hline Л & 0 & 0 & 0 & 0 & 0 & ) & 0 & 0 & 0 & 0 & 0 & 0 & 0 & 0 & 0 & 30 & 0 & 0 & 0 & 0 & 0 & 0 & 0 & 0 & 0 & & 0 & 0 & 0 & 0 & 0 & 0 & 0 & 0 & 0 \\
\hline Љ & 0 & 0 & 0 & 0 & 0 & & 0 & 0 & 0 & 0 & 0 & 0 & 0 & 0 & 0 & 0 & 4 & 0 & 0 & 0 & 0 & 0 & 0 & 0 & 0 & & 0 & 0 & 0 & 0 & 0 & 0 & 0 & 0 & 0 \\
\hline $\mathrm{M}$ & 0 & 0 & 0 & 0 & 0 & & 0 & 0 & 0 & 0 & 0 & 0 & 0 & 0 & 0 & 0 & 0 & 28 & 0 & 0 & 0 & 0 & 0 & 0 & 0 & & 0 & 0 & 0 & 0 & 0 & 0 & 0 & 0 & 0 \\
\hline $\mathrm{H}$ & 0 & 0 & 0 & 0 & 0 & & 0 & 0 & 0 & 0 & 0 & 0 & 0 & 0 & 0 & 0 & 0 & 0 & 71 & 0 & 0 & 0 & 0 & 0 & 0 & & 0 & 0 & 0 & 0 & 0 & 0 & 0 & 0 & 0 \\
\hline Њ & 0 & 0 & 0 & 0 & 0 & & 0 & 0 & 0 & 0 & 0 & 0 & 0 & 0 & 0 & 0 & 0 & 0 & 0 & 5 & 5. & 0 & 0 & 0 & 0 & & 0 & 0 & 0 & 0 & 0 & 0 & 0 & 0 & 0 \\
\hline $\mathrm{O}$ & 0 & 0 & 0 & 0 & 0 & ) & 0 & 0 & 0 & 0 & 0 & 0 & 0 & 0 & 0 & 0 & 0 & 0 & 0 & 0 & 0 & 84 & 0 & 0 & 0 & & 0 & 0 & 0 & 0 & 0 & 0 & 0 & 0 & 0 \\
\hline$\Pi$ & 0 & 0 & 0 & 0 & 0 & & 0 & 0 & 0 & 0 & 0 & 4 & 0 & 0 & 0 & 0 & 0 & 0 & 29 & 0 & 0 & 0 & 25 & 0 & 0 & & 0 & 0 & 0 & 0 & 0 & 0 & 0 & 0 & 0 \\
\hline $\mathrm{P}$ & 0 & 0 & 1 & 0 & 0 & 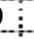 & 0 & 0 & 0 & 0 & 0 & 0 & 0 & 0 & 0 & 0 & 0 & 0 & 0 & 0 & 0 & 0 & 0 & 66 & 0 & & 0 & 0 & 0 & 0 & 0 & 0 & 0 & 0 & 0 \\
\hline $\mathrm{C}$ & 0 & 0 & 0 & 0 & 0 & ) & 0 & 0 & 0 & 0 & 0 & 0 & 0 & 0 & 0 & 0 & 0 & 0 & 0 & 0 & 0 & 0 & 0 & 0 & 56 & & 0 & 0 & 0 & 0 & 0 & 0 & 0 & 0 & 0 \\
\hline $\mathrm{T}$ & 0 & 0 & 0 & 0 & 0 & & 0 & 0 & 0 & 0 & 0 & 0 & 0 & 0 & 0 & 0 & 0 & 0 & 0 & 0 & 0 & 0 & 0 & 0 & 0 & & 46 & 0 & 0 & 0 & 0 & 0 & 0 & 0 & 0 \\
\hline $\mathrm{h}$ & 0 & 0 & 0 & 0 & 0 & & 0 & 0 & 0 & 0 & 0 & 0 & 0 & 0 & 0 & 0 & 0 & 0 & 0 & 0 & 0 & 0 & 0 & 0 & 0 & & 0 & 3 & 0 & 0 & 0 & 0 & 0 & 0 & 0 \\
\hline $\mathrm{y}$ & 0 & 0 & 0 & 0 & 0 & & 0 & 0 & 0 & 0 & 0 & 0 & 0 & 0 & 0 & 0 & 0 & 0 & 0 & 0 & 0 & 0 & 0 & 0 & 0 & & 0 & 0 & 39 & 0 & 0 & 0 & 0 & 0 & 0 \\
\hline$\Phi$ & 0 & 0 & 0 & 0 & 0 & & 0 & 0 & 0 & 0 & 0 & 0 & 0 & 0 & 0 & 0 & 0 & 0 & 0 & 0 & 0 & 0 & 0 & 0 & 0 & & 0 & 0 & 0 & 4 & 0 & 0 & 0 & 0 & 0 \\
\hline$X$ & 0 & 0 & 0 & 0 & 0 & & 0 & 0 & 0 & $0 \vdots$ & $0:$ & 0 & 0 & 0 & 0 & 0 & 0 & 0 & 0 & 0 & 0 & 0 & 0 & 0 & 0 & & 0 & 0 & 0 & 0 & 8 & 0 & 0 & 0 & 0 \\
\hline Ц & 0 & 0 & 0 & 0 & 0 & & 0 & 0 & 0 & 0 & 0 & 0 & 0 & 0 & 0 & 0 & 0 & 0 & 0 & 0 & 0 & 0 & 0 & 0 & 0 & & 0 & 0 & 0 & 0 & 0 & 10 & 0 & 0 & 0 \\
\hline 4 & 0 & 0 & 0 & 0 & 0 & & 0 & 0 & 0 & 0 & 0 & 0 & 0 & 0 & 0 & 0 & 0 & 0 & 0 & 0 & 0 & 0 & 0 & 0 & 0 & & 0 & 0 & 0 & 0 & 0 & 0 & 5 & 0 & 0 \\
\hline Џ & 0 & 0 & 0 & 0 & 0 & & 0 & 0 & 0 & 0 & 0 & 0 & 0 & 0 & 0 & 0 & 0 & 0 & 0 & 0 & 0 & 0 & 0 & 0 & 0 & & 0 & 0 & 0 & 0 & 0 & 0 & 0 & 0 & 0 \\
\hline Ш & 0 & 0 & 0 & 0 & 0 & & 0 & 0 & 0 & 0 & & 0 & 0 & 0 & $\underline{0}$ & 0 & 0 & 0 & 0 & 0 & 0 & 0 & 0 & 0 & 0 & & 0 & 0 & 0 & 0 & 0 & 0 & 0 & 0 & 9 \\
\hline
\end{tabular}

Table 3. Legend for the results understanding

\begin{tabular}{|c||}
\hline$\Delta$ Characters to be recognized \\
\hline$\Delta$ Recognized characters \\
\hline$\Delta$ Number of correctly recognized characters \\
\hline$\Delta$ Error in recognition number \\
\hline
\end{tabular}

Step two in the classification system design is a character classification with pre-classification and postclassification.

The second approach to the character recognition is based on two main ideas: pre-classification that consists of an additional character analysis before using the neural network for the classification and includes prior knowledge information and post-classification: consists of an additional character analysis after the neural network classification, in order to make a final decision of the recognized character. Pre-classification and postclassification are important parts of the image processing algorithms that consist of the image segmentation and pixel level analysis [5].

In the pre-classification analysis a new parameter is introduced. The percentage of coloration of the central part of segment is a new parameter, calculated from the variables shown in Fig.5. $Z$ parameter is experimentally calculated and it defines the size of the central part of the analyzed segment. Coloration percentage $p$ is a number calculated from a given formula, where $\Delta s$ is coloration of the central part of segment, and $s$ is a total coloration of segment.

$$
\begin{gathered}
u_{1}=\frac{n}{2}+z(n-1) \\
d_{1}=\frac{n}{2}+z(n-1) \\
l_{1}=\frac{m}{2}+z(m-1) \\
r_{1}=\frac{m}{2}-z(m-1) \\
p=\frac{\Delta s}{s} * 100 \%
\end{gathered}
$$

As we can see, we can now split characters in two groups, characters with parameter $\mathrm{p}=0$, and all the other parameters. Characters with $p=0$ are: $\mathrm{O}, \Pi, \mathrm{C}, Ц, \biguplus$ and 
these characters are sent to be processed by one neural network, while the other characters are sent to the other network. This solution was created in order to separate the letter " $\Pi$ " from" $H$ " and " $И "$, since a great number of errors was exactly with these characters. In this case we also have an easier recognition by the network because now there are two networks with the lower number of target vectors.

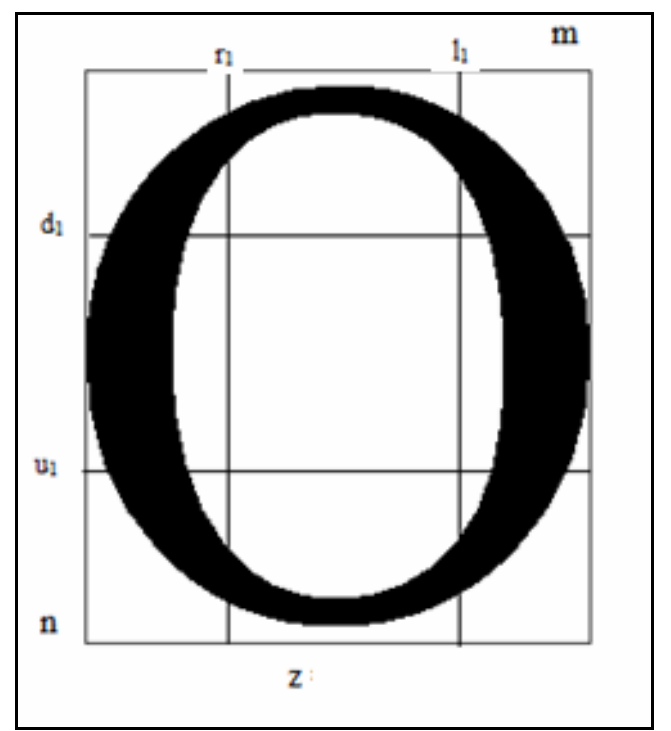

Figure 5. Variables for calculation of the percentage of coloration of the central part of segment

Post-classification part consists of the additional analysis of specific characters recognized by the network. Postclassification is done for the letters with big error percentage, such as "H" recognized as " $И "$, and "3" recognized as "J". The post-classification method is based on a row pixel sum of each character.

For case of " $H$ " letter recognized as " $И$ " the postclassification method is discussed. The most common error is " $H$ " recognized as " $И$ ". In Figures 6 and 7 a row pixel sum of each analyzed character is shown.

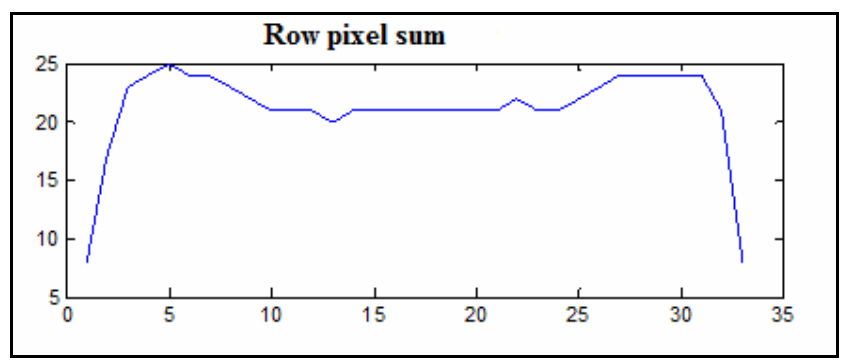

Figure 6. Row pixel sum letter I

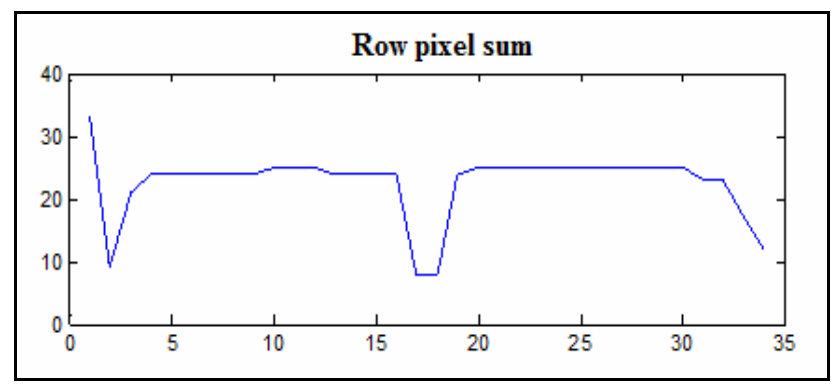

Figure 7. Row pixel sum letter N

As we can see in Fig.7, where row pixel sum for letter " $\mathrm{H}$ " is shown, for pixels between 15 and 30 the value of row pixel sum drastically decreases, whereas this does not happen with letter " $И$ ", except if the scanned character is damaged.
Based on this analysis, a new post processing method is added in the recognition algorithm: when the network classifies a letter as " $И "$, then this character is analyzed according to the post-classification method explained, and the final decision is given whether it is " $\mathrm{H}$ " or " $И$ " letter.

Now, a post-classification method in case of "J" recognized as " 3 " is introduced. Another common error of the neural network first approach is the letter "J" recognized as "3". Again, a row pixel sum of each letter is analyzed, and the post-classification method is designed.

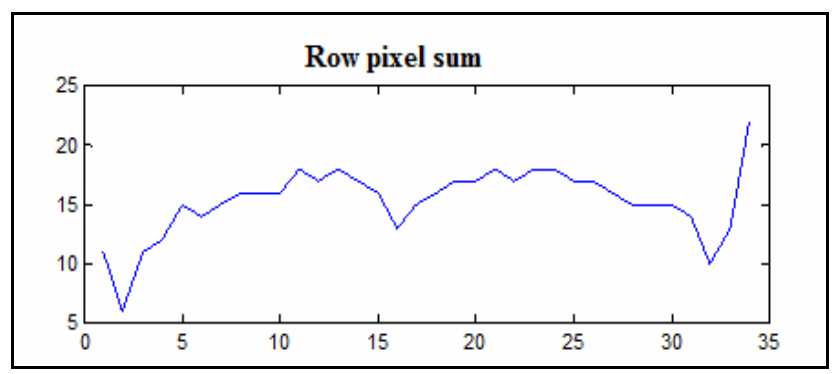

Figure 8. Row pixel sum letter "3"

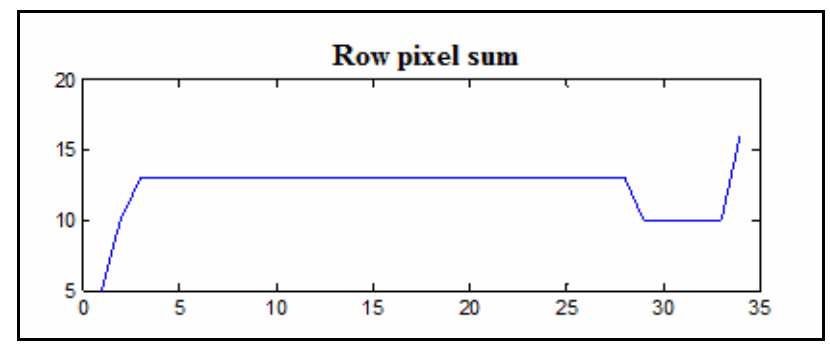

Figure 9. Row pixel sum letter $\mathrm{J}$

In Figures 8 and 9 a row pixel sum of each analyzed character is shown. When the row pixel sum graphs for each letter are analyzed, it is obvious that between the $5^{\text {th }}$ and $25^{\text {th }}$ pixel of "J" letter value of a row pixel sum is equal, whereas this is not the case for the letter " 3 ". That is how the postclassification part of the algorithm is designed.

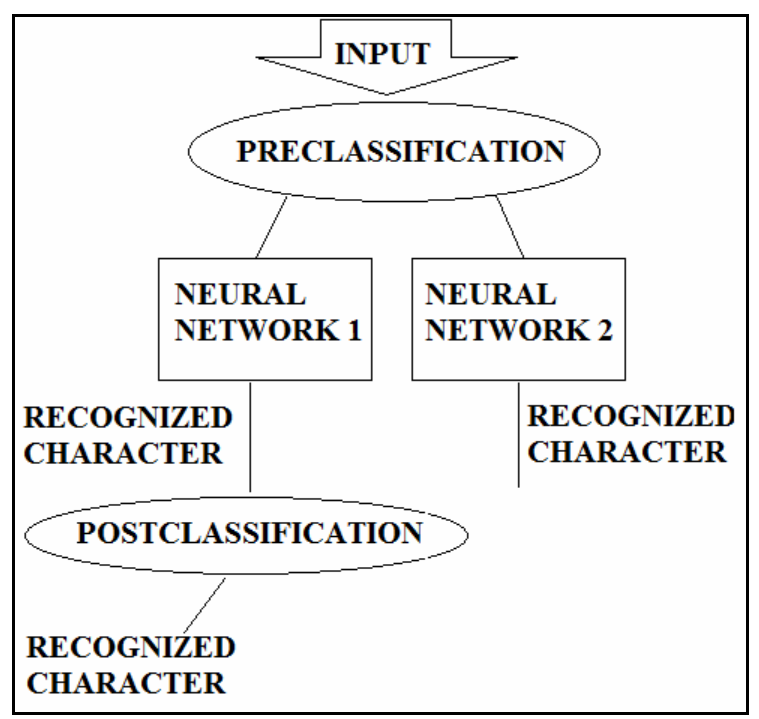

Figure 10. Final design of the recognition system

The final design of the recognition system is shown in Fig.10. Input pattern is a character to be analyzed. Preclassification part consists of the initial pattern classification in one of the two existing groups. One group is for characters with the percentage of coloration of the central part of segment $p=0$, and in the other group are all the other characters of the Cyrillic alphabet. Then, these characters are sent to recognition by the neural networks 1 
and 2. After recognition by the neural network 1 the character is sent to the post-classification in order to make a final recognition decision. In case of the neural network 2 , the post-classification is not necessary.

Tested document is the same as in the first algorithm, as our goal was to decrease error percentage from the first approach. The results are presented in Table 4:

Table 4. Testing results of character classification with pre-classification and post-classification

\begin{tabular}{||c|c|}
\hline Number of tested characters & 1030 \\
\hline Errors & 5 letters \\
\hline Error percentage & $0.48 \%$ \\
\hline
\end{tabular}

Testing results of character classification with preclassification and post-classification are shown in Table 5.

Comparing the results obtained in step one with only one Hopfield network and 30 characters base, it is obvious that common error sources are no longer present. Even now, algorithm can have a bad recognition result, but error percentage is very low, and there are no common errors, but some stochastic error sources. In addition, it is important to stress out that title, with the font size different from the font size of the rest of analyzed text, was also tested, and the recognition was successful. Based on the statistical results, the conclusion is that the new algorithm is with a low error percentage and better performance than the first one analyzed.

\section{Conclusion}

In this paper an approach to the pattern recognition is presented, based on the Hopfield neural network and additional image processing techniques. Patterns that are recognized are capital letters in Cyrillic alphabet. This algorithm is tested on a real scanned document. The chosen classification method is discrete recurrent Hopfield neural network. Before a neural network can be used, an important step is document and character image preparation for recognition by forming the network input vectors.

It is shown that a neural network itself can give better results with some additional techniques. That is why two steps of classification process are shown. Results from the classification step one showed some common classification error sources that formed a base for new improved algorithm described in step two.

The first step presents character classification based on one neural network with 30 characters base. Results obtained in this step revealed common classification error sources. These errors were present only in case of few specific characters. That formed a base for the improved classification method, with the additional binary image parameters. Additional pre-processing parameter enabled a separation of characters into two groups sent to two different neural networks with a lower number of base patterns. Next step was adding new post-classification parameters for the final decision making. Now, in step two, a character classification method gave better results. Both steps are shown in order to present how the final algorithm idea was designed.

This algorithm is sensitive, and does not give good results when the document is damaged. The best results are obtained if the scanned document quality is good. Robustness of the algorithm can be improved by adding some new pre-processing and post-processing techniques.

Algorithm described in this paper represents a base for more sophisticated pattern recognition methods that can have multiple purpose in military applications. Pattern recognition algorithms play an important role in any kind of automated recognition method, such as target recognition in missile guidance, UAV image processing: recognition of visual landmarks, automated vehicle detection and classification by a typical noise pattern recognition and many others [11], [12]

Table 5. Matrix representation of the results of character classification with 30 characters base Hopfield neural network

\begin{tabular}{|c|c|c|c|c|c|c|c|c|c|c|c|c|c|c|c|c|c|c|c|c|c|c|c|c|c|c|c|c|c|c|c|c|c|c|c|c|c|c|}
\hline & $\overline{\mathrm{A}}$ & $\overline{\bar{b}}$ & & B & $\bar{\Gamma}$ & $\overline{7}$ & $\bar{\lambda}$ & & $\bar{b}$ & $\bar{E}$ & & $\bar{W}$ & 3 & $\overline{\bar{U}}$ & & $\mathrm{~J}$ & $\overline{\mathrm{K}}$ & 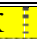 & ת & Љ & $\bar{M}$ & $\bar{H}$ & $\bar{I}$ & Ђ & O & $\overline{\Pi \Pi}$ & $\bar{P}$ & $\bar{C}$ & $\mathrm{~T}$ & $\bar{h}$ & & $\overline{\mathrm{y}}$ & $\Phi$ & $\mathrm{X}$ & 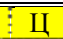 & $\overline{\mathrm{Y}}$ & $\amalg$ & "ШШ \\
\hline $\mathrm{A}$ & 136 & 0 & & 0 & 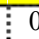 & 0 & 0 & & 0 & 0 & & 0 & 0 & 0 & & 0 & 0 & 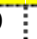 & 0 & 0 & 0 & $\vdots 0$ & ) & 0 & 0 & 0 & 0 & 0 & 0 & 0 & 0 & 0 & 0 & 0 & 0 & 0 & 0 & 0 \\
\hline Б & 0 & 13 & & 0 & & 0 & 0 & & 0 & 0 & & 0 & 0 & 0 & ) & 0 & 0 & & 0 & 0 & 0 & 0 & ) & 0 & 0 & 0 & 0 & 0 & 0 & 0 & 0 & 0 & 0 & 0 & 0 & 0 & 0 & 0 \\
\hline B & 0 & 0 & & 33 & & 0 & 0 & & 0 & 0 & & 0 & 0 & 0 & 5 & 0 & 0 & & 0 & 0 & 0 & 1 & [ & 0 & 0 & 0 & 0 & 0 & 0 & 0 & & 0 & 0 & 0 & 0 & 0 & 0 & 0 \\
\hline & 0 & 0 & & 0 & 2 & 4 & 0 & & 0 & 0 & & 0 & 0 & 0 & ) & 0 & 0 & & 0 & 0 & 0 & 0 & ) & 0 & 0 & 0 & 0 & 0 & 0 & 0 & 0 & 0 & 0 & 0 & 0 & $0:$ & 0 & 0 \\
\hline$\Omega$ & 0 & 0 & & 0 & & 0 & 38 & & 0 & 0 & & 0 & 0 & 0 & ) & 0 & 0 & & 0 & 0 & 0 & 0 & 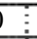 & 0 & 0 & 0 & 0 & 0 & 0 & 0 & & 0 & 0 & 0 & 0 & 0 & 0 & 0 \\
\hline b & 0 & 0 & & 0 & 0 & 0 & 0 & & 3 & 0 & & 0 & 0 & 0 & ) & 0 & 0 & & 0 & 0 & 0 & 0 & ) & 0 & 0 & 0 & 0 & 0 & 0 & 0 & & 0 & 0 & 0 & 0 & 0 & 0 & 0 \\
\hline $\mathrm{E}$ & 0 & 0 & & 2 & 0 & 0 & 0 & & 0 & 98 & & 0 & 0 & 0 & ) & 0 & 0 & & 0 & 0 & 0 & $\vdots 0$ & ) & 0 & 0 & 0 & 0 & 0 & 0 & 0 & & 0 & 0 & 0 & 0 & 0 & 0 & 0 \\
\hline Ж & 0 & 0 & & 0 & & 0 & 0 & & 0 & 0 & & 4 & 0 & 0 & 5 & 0 & 0 & & 0 & 0 & 0 & 0 & ) & 0 & 0 & 0 & 0 & 0 & 0 & 0 & & 0 & 0 & 0 & 0 & 0 & 0 & 0 \\
\hline 3 & 0 & 0 & & 0 & 0 & 0 & 0 & & 0 & 0 & & 0 & 27 & 0 & 5 & 0 & 0 & & 0 & 0 & 0 & 0 & 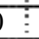 & 0 & 0 & 0 & 0 & 0 & 0 & 0 & & 0 & 0 & 0 & 0 & 0 & 0 & 0 \\
\hline И & 0 & 0 & $0 \vdots$ & 0 & 0 & 0 & 0 & & 0 & 0 & & 0 & 0 & 86 & 6 & 0 & $\vdots 0$ & 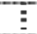 & 0 & 0 & 0 & $\vdots 0$ & ) & 0 & 0 & 0 & $\vdots 0$ & 0 & 0 & 0 & & 0 & 0 & 0 & 0 & $0 \vdots$ & 0 & 0 \\
\hline $\mathrm{J}$ & 0 & 0 & & 0 & 0 & 0 & 0 & & 0 & 0 & & 0 & 0 & 0 & ) & 32 & 0 & & 0 & 0 & 0 & $\therefore 0$ & ) & 0 & 0 & 0 & 0 & 0 & 0 & 0 & & 0 & 0 & 0 & 0 & 0 & 0 & 0 \\
\hline K & 0 & 0 & & 0 & 0 & 0 & 0 & & 0 & 0 & & 0 & 0 & 0 & ) & 0 & 37 & & 0 & 0 & 0 & 0 & ) & 0 & 0 & 0 & 0 & 0 & 0 & 0 & & 0 & 0 & 0 & 0 & 0 & 0 & 0 \\
\hline$\pi$ & 0 & 0 & & 0 & 0 & 0 & 0 & ( & 0 & 0 & & 0 & 0 & 0 & & 0 & 0 & & 30 & 0 & 0 & 0 & ) & 0 & 0 & 0 & 0 & 0 & 0 & 0 & & 0 & 0 & 0 & 0 & 0 & 0 & 0 \\
\hline Љ & 0 & 0 & & 0 & 0 & 0 & 0 & & 0 & 0 & & 0 & 0 & 0 & & 0 & 0 & & 0 & 4 & 0 & $\vdots 0$ & 5 & 0 & 0 & 0 & 0 & 0 & 0 & 0 & & 0 & 0 & 0 & 0 & 0 & 0 & 0 \\
\hline M & 0 & 0 & & 0 & & 0 & 0 & & 0 & 0 & & 0 & 0 & 0 & & 0 & 0 & & 0 & 0 & 28 & 0 & 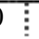 & 0 & 0 & 0 & 0 & 0 & 0 & 0 & & 0 & 0 & 0 & 0 & $0 \stackrel{0 !}{0 !}$ & 0 & 0 \\
\hline : & 0 & $\overline{0}$ & 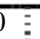 & $\overline{0}$ & 0 & 0 & 0 & & 0 & 0 & & 0 & 0 & 0 & 5 & 0 & 0 & & 0 & 0 & 0 & $\overline{71}$ & 1 & $\overline{0}$ & 0 & 0 & 0 & 0 & 0 & 0 & & 0 & 0 & 0 & 0 & 0 & 0 & $\overline{0}$ \\
\hline B & 0 & 0 & & 0 & & 0 & 0 & & 0 & 0 & & 0 & 0 & 0 & & 0 & 0 & & 0 & 0 & 0 & 0 & ) & 5 & 0 & 0 & 0 & 0 & 0 & 0 & & 0 & 0 & 0 & 0 & 0 & 0 & 0 \\
\hline $\mathrm{O}$ & 0 & 0 & & 0 & & 0 & 0 & & 0 & 0 & & 0 & 0 & 0 & & 0 & 0 & & 0 & 0 & 0 & 0 & ) & 0 & 84 & 0 & 0 & 0 & 0 & 0 & & 0 & 0 & 0 & 0 & 0 & 0 & 0 \\
\hline$\Pi$ & 0 & 0 & ) & 0 & & 0 & 0 & & 0 & 0 & & 0 & 0 & 0 & & 0 & 0 & & 0 & 0 & 0 & 0 & ) & 0 & 0 & 26 & 0 & 0 & 0 & 0 & & 0 & 0 & 0 & 0 & 0 & 0 & 0 \\
\hline & 0 & 0 & ) & 1 & & 0 & 0 & & 0 & 0 & & 0 & 0 & 0 & 5 & 0 & 0 & & 0 & 0 & 0 & 0 & ) & 0 & 0 & 0 & 67 & 0 & 0 & 0 & & 0 & 0 & 0 & 0 & 0 & 0 & 0 \\
\hline C & 0 & 0 & & 0 & & 0 & 0 & & 0 & 0 & & 0 & 0 & 0 & & 0 & 0 & & 0 & 0 & 0 & 0 & ) & 0 & 0 & 0 & 0 & 56 & 0 & 0 & & 0 & 0 & 0 & 0 & 0 & 0 & 0 \\
\hline $\mathrm{T}$ & 0 & 0 & $0 \vdots$ & 0 & 0 & 0 & 0 & & 0 & 0 & $\vdots$ & 0 & 0 & 0 & & 0 & 0 & & 0 & 0 & 0 & $\vdots 0$ & & 0 & 0 & 0 & 0 & 0 & 46 & 0 & & 0 & 0 & 0 & 0 & $0 \vdots$ & 0 & 0 \\
\hline $\mathrm{h}$ & 0 & 0 & & 0 & & 0 & 0 & & 0 & 0 & & 0 & 0 & 0 & & 0 & 0 & & 0 & 0 & 0 & 0 & ) & 0 & 0 & 0 & 0 & 0 & 0 & 3 & & 0 & 0 & 0 & 0 & 0 & 0 & 0 \\
\hline $\mathrm{y}$ & 0 & $\overline{0}$ & & 0 & & 0 & 0 & & 0 & 0 & & 0 & 0 & 0 & ) & 0 & 0 & & 0 & 0 & 0 & 0 & ) & 0 & 0 & 0 & 0 & 0 & 0 & 0 & & 9 & 0 & 0 & 0 & 0 & 0 & 0 \\
\hline$\Phi$ & 0 & 0 & $0 \vdots$ & 0 & & 0 & 0 & & 0 & 0 & & 0 & 0 & 0 & & 0 & 0 & & 0 & 0 & 0 & 0 & ) & 0 & 0 & 0 & 0 & 0 & 0 & 0 & & 0 & 4 & 0 & 0 & 0 & 0 & 0 \\
\hline $\mathrm{X}$ & 0 & 0 & & 0 & & 0 & 0 & & 0 & 0 & & 0 & 0 & 0 & & 0 & 50 & & 0 & 0 & 0 & 0 & 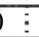 & 0 & 0 & 0 & 0 & 0 & 0 & 0 & & 0 & 0 & 8 & 0 & 0 & 0 & $\overline{0}$ \\
\hline Ц & 0 & 0 & & 0 & & 0 & 0 & & 0 & 0 & & 0 & 0 & 0 & & 0 & 0 & & 0 & 0 & 0 & 0 & ) & 0 & 0 & 0 & 0 & 0 & 0 & 0 & & 0 & 0 & 0 & 10 & 0 & 0 & 0 \\
\hline 4 & 0 & 0 & & 0 & & 0 & 0 & & 0 & 0 & & 0 & 0 & 0 & & 0 & 0 & & 0 & 0 & 0 & 0 & ) & 0 & 0 & 0 & 0 & 0 & 0 & 0 & & 0 & 0 & 0 & 0 & 5 & 0 & 0 \\
\hline$\amalg$ & 0 & 0 & & 0 & & 0 & 0 & & 0 & 0 & & 0 & 0 & 0 & & 0 & 0 & & 0 & 0 & 0 & 0 & 5 & 0 & 0 & 0 & 0 & 0 & 0 & 0 & & 0 & 0 & 0 & 1 & 0 & 0 & 0 \\
\hline Ш & 0 & 0 & & 0 & & 0 & 0 & & 0 & 0 & & 0 & 0 & 0 & & 0 & 0 & & 0 & 0 & 0 & 0 & ) & 0 & 0 & 0 & 0 & 0 & 0 & 0 & & 0 & 0 & 0 & 0 & 0 & 0 & $\overline{9}$ \\
\hline
\end{tabular}


A good example is also the multiple-target tracking (MTT), an essential requirement for the surveillance systems employing one or more sensors, along with the computer subsystems. Primary sensors for the detection and target tracking are radars, as the active sensors, but they are increasingly supplemented with the passive sensors as infrared cameras. The signals arriving from many sensors are processed in order to establish the estimation, prediction and tracking of air moving targets over the state territory or a region of interest [13]. This is the area where pattern recognition algorithms can have a significant role and impact on the system's performance.

\section{Reference}

[1] MARQUES de SÁ,J.P.: Pattern Recognition Concepts, Methods and Applications, Springer Science \& Business Media, 2012.

[2] JAVIDI,B.,: Image Recognition and Classification, CRC Press, 2002.

[3] ELMORE,M., MARTONOSI,M.: A Morphological Image Preprocessing Suite for OCR on Natural Scene Images, 2008.

[4] GRAOVAC,S.: Automatic Guidance of Objects in Space', Akademska misao, Belgrade, 2006

[5] EGMONT-PETERSEN,M., DE RIDDER,D., HANDELS,H.: Image processing with neural networksa review, Pattern Recognition,
2001, Vol. 35, pp.2279-2301.

[6] KLJAJIĆ,N.: Optical character recognition based on Hopfield neural networks, Master thesis, Faculty of Electrical Engineering, University of Belgrade, Belgrade, 2011.

[7] PALM,G.: Neural associative memories and sparse coding, Neural Networks, 2013, Vol.37, pp.165-171

[8] BRČIC,F.: Hopfield neural networks, Master thesis, Faculty of Electrical Engineering, University of Belgrade, Belgrade, 2011.

[9] Cambridge University Press: Postscript on Supervised Neural Networks, 2003

[10] The MathWorks, Inc, Matlab Product Help

[11] MICHAELSEN,E., MEIDOW,J.: Stochastic reasoning for structural pattern recognition: An example from image-based UAV navigation, Pattern Recognition, doi:10.1016/j.patcog.2014.02.009, 2014.

[12] BERDNIKOVA,J., RUUBEN,T., KOZEVNIKOV,V., ASTAPOV,S.: Acoustic Noise Pattern Detection and Identification Method in Doppler System, Elektronika Ir Elektrotechnika, ISSN 1392-1215, 2012, Vol. 18, No. 8.

[13] RADOSAVLJEVIĆ,Z., $\quad$ NIKOLIĆ,M., $\quad$ NOVKOVIĆ,M., OBRADOVIĆ,Lj.: The description of some moving air target tracking algorithms, Scientific Technical Review, ISSN 1820-0206, 2005, Vol.LV, No.3-4, pp.59-65.

\title{
Projektovanje hijerarhijskog sistema za optičko prepoznavanje karaktera zasnovano na Hopfildovim neuralnim mrežama
}

\begin{abstract}
Prepoznavanje oblika je naučna disciplina koja se bavi metodama za opisivanje i klasifikaciju objekata, a optičko prepoznavanje karaktera predstavlja jednu granu istraživanja ove naučne discipline. U ovom radu je predstavljen metod projektovanja hijerarhijskog sistema za optičko prepoznavanje karaktera. Opisana strategija klasifikacije je bazirana na Hopfildovim neuralnim mrežama i metodama obrade slike. Karakteri za prepoznavanje su velika slova ćiriličnog pisma. Prvi korak u dizajnu predstavlja testiranje rada neuralne mreže na realnom skeniranom dokumentu. Na osnovu rezultata dobijenih ovim testiranjem sa jednom Hopfildovom neuralnom mrežom, otkriveni su česti izvori grešaka sistema. Ovi izvori grešaka predstavljaju bazu za nova poboljšanja algoritma i samog sistema za prepoznavanje. Sledeći korak je dodavanje novih parametara za obradu binarnih slika, kao i metoda za preprocesiranje i postprocesiranje radi otklanjanja tipičnih grešaka. Nakon testiranja identičnog realnog skeniranog dokumenta, dobijeni rezultati novog poboljšanog sistema pokazuju znatno smanjenje verovatnoće greške.
\end{abstract}

Ključne reči: raspoznavanje oblika, raspoznavanje karaktera, optičko raspoznavanje, sistem za raspoznavanje oblika, hijerarhijski sistem, neuralna mreža, asocijativna memorija.

\section{Conception du système hiérarchique pour la reconnaissance optique des caractères basés sur les réseaux neuraux de Hopfield}

\begin{abstract}
La reconnaissance des formes est une discipline scientifique qui s'occupe des méthodes pour la description et la classification des objets et elle représente une branche des recherches de cette discipline scientifique. Dans ce travail on a présenté la méthode de la conception du système hiérarchique pour la reconnaissance optique des caractères. On a déerit la stratégie de classification basée sur les réseaux neuraux de Hopfield et sur les méthodes pour le traitement de l'image. Les caractères pour la reconnaissance sont les lettres majuscules de l'alphabet cyrillique. Le premier pas dans le dessin est l'examen du fonctionnement du réseau neural à partir d'un document réel scanné. A la base des résultats obtenus par cet examen avec un réseau neural de Hopfield on a découvert les fréquences sources des erreurs du système. Ces sources des erreurs représentent la base pour nouvelles améliorations d'algorithme et du système de reconnaissance. Le pas suivant est l'addition de nouveaux paramètres pour le traitement des images binaires ainsi que la méthode pour le pré traitement et post traitement dans le but d'éliminer les erreurs typiques. Après l'examen du document réel scanné les résultats obtenus par le nouveau système amélioré démontrent une diminution considérable de la probabilité de l'erreur.
\end{abstract}




\title{
Проектирование иерархической системы оптического распознавания символов, основанное на нейронных сетях Хопфилда
}

\begin{abstract}
Распознавание образов является научной дисциплиной, которая имеет дело с методами для описания и классификации объектов, пока оптическое распознавание символов представляет только одну ветвь исследования этой научной дисциплины. Эта статья представляет собой метод для разработки иерархической системы для оптического распознавания символов. Представленная стратегия классификации основана на нейронных сетях Хопфилда и на методах обработки изображений. Символы для распознавания - большие буквы кириллицы. Первым шагом в дизайне является работа тестирования нейронных сетей в режиме реального отсканированного документа. На основании результатов, полученных в этом тесте с подобной нейронной сетью Хопфилда, были обнаружены частые источники ошибок в системе. Эти источники ошибок являются основой для новых совершенствований алгоритма и самой системы распознавания. Следующим шагом надо добавить новые параметры для обработки бинарных изображений, а также и способы для предварительной обработки и постобработки, чтобы устранить типичные ошибки. После тестирования идентичного реального отсканированного документа, полученные результаты новой улучшенной системы показали значительное уменьшение вероятности ошибок.
\end{abstract}

Ключевые слова: распознавание образов, распознавание символов, оптическое распознавание символов, система распознавания образов, иерархическая система, нейронные сети, ассоциативная память. 